\title{
A scientific note on genetic profile of the mite Varroa destructor infesting apiaries in Rio Grande do Sul state, Brazil
}

\author{
Carla Elizabete Octaviano-Salvadé ${ }^{1}$, Carlos Eduardo Leher ${ }^{1}$, David De Jong ${ }^{2}$, Paulo Marcos Pinto ${ }^{1}$, \\ Andrés Delgado-CAÑEDo ${ }^{1}$, Juliano Tomazzoni Boldo ${ }^{1}$ \\ ${ }^{1}$ APIPAMPA, Fundação Universidade Federal do Pampa, Campus São Gabriel, São Gabriel, RS, Brazil \\ ${ }^{2}$ Departamento de Genética; Ribeirão Preto, Universidade de São Paulo, São Paulo, SP, Brazil
}

Received 16 September 2016 - Revised 19 January 2017 - Accepted 8 March 2017

mite / Africanized bees / haplotype / genetic characterization / CO-I gene

The Varroa destructor mite is a hematophagous ectoparasite widely known as the most important Apis mellifera parasite; it causes severe economic impact on beekeeping, since in most regions of the world colonies infested with $V$. destructor eventually collapse (Strapazzon et al. 2009; Rosenkranz et al. 2010). Different mite haplotypes present distinct reproductive capacity and virulence factors (Anderson and Trueman 2000; Garrido et al. 2003; Strapazzon et al. 2009), which contribute to infestation rates and consequent damage to honey bee colonies.

We examined the prevalence of Japan $(J)$ and Korean $(K)$ mitochondrial haplotypes of the mites infesting A. mellifera from southwestern Rio Grande do Sul state, an important Brazilian honey-producing region that borders Argentina (to the west) and Uruguay (to the south), both of which have severe problems with $V$. destructor infestations. Given the higher infestation levels in cold regions of Brazil (Moretto et al. 1991) and the tendency for beekeepers in this southernmost region of the country to copy management practices used in the neighboring countries, there is a considerable concern about Varroa infestations.

This study was carried out between May 2013 and November 2015 and sampled phoretic adult females of $V$. destructor, 47 in total, from adult workers from arbitrarily selected beehives. One known $V$. destructor haplotype $J$ mite sample from Fernando de Noronha Island

Corresponding author: J. Boldo, julianoboldo@unipampa.edu.br Manuscript editor: Peter Rosenkranz
(Pernambuco State) was collected and used for comparison. The molecular analysis of the CO-I mitochondrial gene using PCR-restriction enzyme, as described in Anderson and Fuchs (1998), and sequencing and alignment experiments indicated all 47 mite samples of the southwestern region of Rio Grande do Sul state belong to the Korean $(K)$ haplotype pattern. Only the Fernando de Noronha Island sample showed the haplotype $J$ pattern, although the Japan $(J)$ haplotype was formerly reported in the region (Strapazzon et al. 2009). All PCR amplicons presented the expected 458 base pairs and had $100 \%$ identity to previously reported sequences.

The sequences obtained from our southwestern samples (GenBank accession numbers: KX458254.1 and KY380010-KY380055) were identical to one another and to the previously reported $V$. destructor $\operatorname{Korean}(K)$ haplotype, with the same genetic pattern that was found in Argentina (Guerra et al. 2010). As expected, only the Xho I restriction site was observed. The sequence obtained from the Fernando de Noronha Island sample (GenBank accession number: KX458253.1) were identical to the previously reported $V$. destructor Japan haplotype (Anderson and Trueman 2000) and showed the presence of both Xho I and Sac I restriction sites. None of the southwestern samples were cut by the Sac I endonuclease, as it is a characteristic of the $V$. destructor Korean haplotype, while the Fernando Noronha Island samples were cut by Sac I, as it is a characteristic of $V$. destructor Japan haplotype, as reported before (Anderson and Trueman 2000).

These data agree with previous studies that showed that the Japanese haplotype has more 
restricted distribution than the Korean haplotype (Anderson and Trueman 2000; Strapazzon et al. 2009; Rosenkranz et al. 2010) and was only found in Brazil in Fernando de Noronha Island (Guerra et al. 2010), Vale do Paraíba (São Paulo State), and Sul Fluminense (Rio de Janeiro State) (Pinto 2012).

We now have a new evidence to corroborate that the $V$. destructor Korean haplotype population is growing rapidly in southern Brazil, where the Japan haplotype formerly existed (Anderson 2000; Anderson and Trueman 2000; Carneiro et al. 2007) and support the hypothesis of genotype substitution occurring over time (Anderson and Trueman 2000; Guerra et al. 2010; Pinto 2012).

The intensity of damage caused by $V$. destructor mites has been shown to vary according to the infestation levels in a given region (Moretto and Mello 1999; Guerra et al. 2010; Pinto 2012). The honey bees present in the sampled region are characterized as Africanized bees (Wallberg et al. 2014), and it appears that the Africanized honey bees in Brazil are able to keep infestation rates at low levels, compared to what has been found in other countries (Moretto et al. 1991; Strapazzon et al. 2009); climate could be one of the factors involved (De Jong et al. 1984), despite the predominance of the $K$ haplotype. Our results clarify the nature of the southwest Rio Grande do Sul $V$. destructor mite population and suggest that interactions between environment and reproduction ability of genetically distinct populations of $V$. destructor infesting Africanized honey bees throughout Brazil may play a significant role in prevalence and levels of infections. To our knowledge, this is the first comprehensive $V$. destructor genetic profile survey in this region bordering between subtropical and temperate regions of Brazil.

\section{ACKNOWLEDGEMENTS}

We are thankful to the beekeepers from Rio Grande do Sul state and from Fernando de Noronha Island, Pernambuco state, for allowing us to collect $V$. destructor samples. This study was supported by the MCTI/CNPq (14/2013-UNIVERSAL) process number 473528/2013-4.

Contributions CEOS and CEPL performed the experiments, participated in the interpretation of data, and wrote the paper. DDJ, PMP, ADC, and JTB conceived this research, designed the experiments, and reviewed the manuscript.
Note scientifique sur le profil génétique de l'acarien Varroa destructor infestant les ruchers dans l'État du Rio Grande do Sul, au Brésil.

Eine wissenschaftliche Notiz über genetisches profil der milbe Varroa Destructor befallen Bienenstöcke in Rio Grande do Sul Staat, Brasilien.

\section{REFERENCES}

Anderson, D.L. (2000) Variation in the parasitic bee mite Varroa jacobsoni Oud. Apidologie 31, 281-292

Anderson, D.L., Fuchs, S. (1998) Two genetically distinct populations of Varroa jacobsoni with contrasting reproductive abilities on Apis mellifera. J. Apicult. Res. 37 (2), 69-78

Anderson, D.L., Trueman J.W.H. (2000) Varroa jacobsoni (Acari: Varroidae) is more than one species. Exp. Appl. Acarol. 24 (3), 165-189

Carneiro, F.E., Torres, R.R., Strapazzon, R., Ramírez, S.A., Guerra, Jr. J.C.V., Koling, D.F., Moretto, G. (2007) Changes in the reproductive ability of the mite Varroa destructor (Anderson and Trueman) in Africanized honey bees (Apis mellifera L.) colonies in southern Brazil. Neotrop. Entomol. 36 (6), 949-952

De Jong, D., Goncalves, L. S., Morse, R.A. (1984) Dependence on climate of the virulence of Varroa jacobsoni. Bee World 65 (3), 117-121

Garrido, C., Rosenkranz, P., Paxton, R.J., Gonçalves, L.S. (2003) Temporal changes in Varroa destructor fertility and haplotype in Brazil. Apidologie 34 (6), 535-541

Guerra, Jr. J.C.V., Issa, M.R.C., Carneiro, F.E., Strapazzon, R., Moretto, G. (2010) RAPD identification of Varroa destructor genotypes in Brazil and other regions of the Americas. Genet. Mol. Res. 9 (1), 303-308

Moretto, G., Mello Jr., L.J. (1999) Varroa jacobsoni infestation of adult Africanized and Italian honey bees (Apis mellifera) in mixed colonies in Brazil. Genet. Mol. Biol. 22 (3), 321-323

Moretto, G., Gonçalves L.S., De Jong, D., Bichuette, M.Z. (1991) The effects of climate and bee race on Varroa jacobsoni Oud. infestation in Brazil. Apidologie 22 (3), 197-203

Pinto, F.A. (2012) Varroa destructor Anderson \& Trueman, 2000 in Africanized honey bees (Apis mellifera 1.): genetic profile, infestation rates and reproduction in Brazil. M. Sc. Thesis, Universidade Federal de Viçosa.

Rosenkranz, P., Aumeier, P., Ziegelmann, B. (2010) Biology and control of Varroa destructor, Invertebr. Pathol. 103, S96-S119

Strapazzon, R., Carneiro, F.E., Guerra, Jr. J.C.V., Moretto, G. (2009) Genetic characterization of the mite Varroa destructor (Acari: Varroidae) collected from honey bees Apis mellifera (Hymenoptera, Apidae) in the state of Santa Catarina, Brazil. Genet. Mol. Res. 8 (3), 990-997

Wallberg, A., Han, F., Wellhagen, G., Dahle, B., Kawata, M., Haddad, N., Simões, Z.L.P., Allsopp, M.H., Kandemir, I., Rúa, P., Pirk, C.W., Webster, M.T. (2014) A worldwide survey of genome sequence variation provides insight into the evolutionary history of the honeybee Apis mellifera . Nat. Gen. 46 (10), 1081-1088 